\title{
Dose-Dependent Effects of Protein Ingestion and Resistance Exercise on Muscle Protein Synthesis in Aging Adults: A Literature Review
}

\author{
Caryn Qian, BHSc Student [1]* \\ [1] Bachelor of Health Sciences Program, McMaster University, Hamilton, Ontario, Canada \\ *Corresponding Author: qian.caryn@gmail.com
}

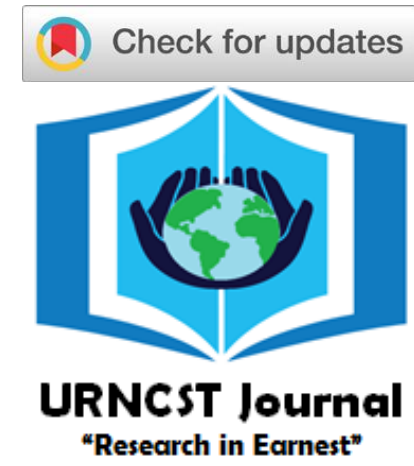

\begin{abstract}
Introduction: Sarcopenia can lead to physical disability and lower quality of life, but increasing muscle protein synthesis in older adults may reduce its effects. Dose-response curves may be used to determine the optimal protein dose in rested and exercised muscle to elicit maximal muscle protein synthesis.

Methods: A literature review was conducted to explore and summarize the findings on the following topics: the mechanisms of muscle protein synthesis, anabolic resistance, and the dose-responses of muscle protein synthesis to anabolic stimuli in both younger and older individuals.

Results: Reduced phosphorylation in downstream targets of the mammalian target of rapamycin complex 1 pathway is characteristic of muscle protein synthesis in older muscle. Compared to younger muscle, older muscle can elicit a similar maximal muscle protein synthesis response, but is less sensitive to lower doses of protein ingestion. With ingestion of $40 \mathrm{~g}$ of whey protein, the fractional synthetic rate in older muscle is similar to that of younger muscle with $20 \mathrm{~g}$ of whey protein ingestion. Marked increases in amino acid oxidation are also observed.

Discussion: Anabolic resistance can be biochemically explained by reduced phosphorylation in the mammalian target of rapamycin complex 1 pathway. Due to this phenomenon, older individuals require greater anabolic stimuli to achieve maximal muscle protein synthesis. However, the most effective protein dose for maximal muscle protein synthesis in older muscle is not well-established.

Conclusion: The muscle protein synthesis dose-response curve for older individuals reveals blunted responses to stimuli due to anabolic resistance. Further research is warranted to determine the optimal protein dose for maximal muscle protein synthesis in older adults.
\end{abstract}

Keywords: muscle protein synthesis; dose-response; protein ingestion; resistance exercise; anabolic resistance; elderly; mTORC1

\section{Introduction}

Sarcopenia, defined as muscle loss with increasing age, has severe implications on frailty and overall mobility [1]. These negative effects can decrease an individual's quality of life and loss of strength could impede everyday functions, such as walking. This gradual phenomenon is accelerated at and past the fifth decade of life [2], and is evident in middleaged and elderly adults. It is characterized by lower muscle protein synthesis (MPS) than breakdown, which together govern overall skeletal muscle mass. Consequently, maximizing MPS in older individuals is key in reducing sarcopenia [3]. However, induction of maximal MPS requires greater stimuli in older than younger adults [4]. Anabolic resistance is the reduced response of MPS to anabolic stimuli and it is often correlated with sarcopenia [4]. This effect is much more prominent in older populations, blunting the sensitivity to stimulate MPS [5].

Despite the effects of anabolic resistance, there is evidence that older individuals can achieve maximal MPS rates approximately equal to those of younger individuals, given greater anabolic stimulus [6]. Two well-studied, measurable stimuli are protein consumption and exercise volume, namely resistance exercise. These two factors work synergistically to increase MPS by stimulating associated pathways. It is well established that resistance exercise heightens MPS compared to the rested state [7], but the protein dosage sufficient to induce maximal MPS without a severe increase in amino acid (AA) oxidation is more unclear, especially in older adults. Comparing the MPS dose-response to protein ingestion between younger and older individuals may reveal effects of anabolic resistance on MPS and warrant investigation into aging effects on the MPS pathways.

\section{Methods}

A literature review was conducted to explore and summarize the findings on the following topics: the mechanisms of MPS, anabolic resistance, and the dose- 
UNDERGRADUATE RESEARCH IN NATURAL AND CLINICAL SCIENCE AND TECHNOLOGY (URNCST) JOURNAL Read more URNCST Journal articles and submit your own today at: https://www.urncst.com

responses of MPS to anabolic stimuli in both younger and older individuals. In this review, young or younger individuals are defined as $\sim 20$ years old and elderly adults are defined as $\sim 70$ years old. Articles were found through the following databases: Ovid Medline, Pubmed, and Web of Science. Key search terms used included "muscle protein synthesis", "elderly", "anabolic resistance", "doseresponse", "mTORC1", and "whey protein". These terms were combined using the boolean operators "and"/ "or". Studies involving dose-response experiments conducted on animal models or were not pertinent to the research question were excluded. In the end, 10 dose-response studies were included and 59 studies were included in total.

\section{Results}

mTORC1 pathway

MPS is activated and regulated through the mammalian target of rapamycin complex 1 (mTORC1), a complex commonly associated with tissue growth and MPS [8-12]. mTORC1 acts as a control center receiving inputs from anabolic stimulants, and upon phosphorylation by mTORC1 kinase, leads to a pathway of downstream targets that upregulate translation of mRNA into protein $[9,12]$. The phosphorylation of mTORC1 triggers the phosphorylation of two key sets of substrates, eukaryotic initiation factor 4E binding proteins 1 and 2 (4E-BP1/2) and ribosomal S6 kinases 1 and 2 (S6K1/2) [8-13]. The 4E-BPs inhibit formation of the eukaryotic initiation factor $4 \mathrm{E}$ (eIF4E) complex, which promotes the smaller 40S subunit to the 5' end of mRNA [12]. Thus, phosphorylation of 4EBPs permits the formation of eIF4E and the translation initiation complex $[8,9,12]$. Phosphorylation of S6K1 results in further phosphorylation of ribosomal protein S6 and eukaryotic elongation factor 2 kinase [9]. These proteins enhance translation initiation and elongation $[9,14]$, and it has been proposed that they play a role in ribosome biogenesis, thereby increasing overall translational capacity in the cell [12].

There are a number of anabolic stimulants that activate MPS, including protein/AA ingestion and muscle contraction. MPS responses are correlated to plasma concentrations of AAs, in particular essential amino acids (EAAs), which are present in many supplemental proteins [13]. Contrastingly, non-essential AAs do not elicit a significant MPS response [15]. Although intramuscular AA concentration is commonly measured in MPS studies, there is no relationship between intramuscular AA concentration and MPS, but there is a single curvilinear relationship between the latter and plasma AA concentration [16]. Leucine, an EAA abundant in whey protein, is an important anabolic AA stimulus that has been associated with phosphorylation of p70S6K1 in the mTORC1 pathway [10]. Intramuscular leucine sensors have also been discovered to activate this pathway, suggesting leucine as a primary AA trigger of MPS [9]. Leucine is also one of three branched-chain AAs, the others being valine and isoleucine, that are essential for muscle synthesis [17]. These AAs, when ingested together, enhance the activity of kinases and translation initiation factors beyond the abilities of leucine independently [17].

There is an upper limit to the MPS response elicited due solely to AA availability in young men, known as the muscle full effect [13]. Beyond this limit, available AAs no longer act as substrates for MPS and are directed to oxidation, with MPS rates falling to postabsorptive rates, despite sustained increased plasma AA concentration and intramuscular signaling [13, 18]. Resistance exercise sensitizes skeletal muscle to the provision of AAs, which potentiates MPS in response to hyperaminoacidemia $[18,19]$.

Muscle contraction from physical activity, especially resistance exercise, is a well-established MPS stimulus [7, 20]. Resistance exercise performed in the fasted state can result in increased mTORC1 activation and subsequently MPS during the first hour of exercise [14, 21], and can remain increased for up to 48 hours [14, 22], although exactly how muscle contraction results in mTORC1 activation is still unknown [23]. Muscle protein breakdown is also elevated in this state [23], thereby supporting the notion that resistance training combined with protein intake enhances MPS beyond the effect of either stimulus by itself. Numerous studies have demonstrated that resistance exercise before protein ingestion increases the anabolic response, but this potentiation is not observed in rested individuals [24-26].

\section{Anabolic resistance}

In experiments investigating the differences between basal MPS between young and elderly individuals, no differences were found $[27,28]$. However, increases to MPS in response to anabolic stimuli is blunted with aging, a concept known as age-induced anabolic resistance [2, 4, 5, 14, 27, 29-31]. This leads to a downward and rightward shift of the dose-response curve between MPS and available plasma AA concentrations [31]. However, it appears that maximal MPS responses are similar, given adequate anabolic stimuli [5, 20, 32].

The cause of age-related anabolic resistance is currently unknown but there are two major proposed factors: the gradual increase in inactivity and the agerelated increase in inflammatory cytokines [33], such as tumor necrosis factor alpha $(\mathrm{TNF}-\alpha)$ and interleukin 6 (IL6) [34]. For the latter, one study using mouse models found that TNF- $\alpha$ was a key determinant in muscle atrophy during sepsis [35]. In humans, TNF- $\alpha$ and IL-6 were found to be markers of anabolic resistance and sarcopenia [36]. Furthermore, TNF- $\alpha$ was also found to interfere with downstream signaling molecules in the mTORC1 pathway to induce decreased MPS [37]. This is in agreement with previous studies that have found that anabolic resistance is correlated with reduced $\mathrm{S} 6 \mathrm{~K} 1$ and $4 \mathrm{E}-\mathrm{BP}$ phosphorylation $[14,28,30,38]$. 
UNDERGRADUATE RESEARCH IN NATURAL AND CLINICAL SCIENCE AND TECHNOLOGY (URNCST) JOURNAL Read more URNCST Journal articles and submit your own today at: https://www.urncst.com

Diet-related obesity and lipid accumulation are also proposed to be correlated with anabolic resistance [39]. Older, inactive, and obese individuals were once categorized as the most at-risk demographic for age-related anabolic resistance [40, 41]. While the reasons for these correlations are still unknown, it is hypothesized that insulin resistance may be the common factor [39]. Dietrelated obesity is often connected to insulin resistance, and downstream effectors in the mTORC pathway have also been identified as contributors to insulin resistance [39].

\section{MPS dose-response in young individuals}

The literature surrounding acute MPS in response to graded protein intakes and resistance exercise is sparse, with almost all studies focused on young ( 20 years old) or elderly $(\sim 70$ years old $)$ men. The results of studies regarding the dose-response of MPS in young adults are presented here [42-44]. Two studies used traditional doseresponse methods, involving multiple graded doses to a maximum of $40 \mathrm{~g}$ of bolus protein, following a bout of resistance-based leg exercises [43-44]. Although the protein used in the studies were different, egg protein [40] versus whey protein [43], both concluded that $20 \mathrm{~g}$ of the respective proteins was sufficient in eliciting a maximal MPS response. $40 \mathrm{~g}$ of protein failed to produce a significantly increased fractional synthetic rate (FSR), the fraction of the protein pool synthesized per unit time [45], but there was a marked increase in AA oxidation [43, 44], in agreement with the muscle full effect. Studies also compared graded dose-responses between rested and nonrested muscles. With increasing doses of whey protein, MPS was greater in all exercised muscles compared to the non-exercised muscles [43, 46], and incorporation of AAs into protein was consistently higher for exercised muscles [5]. This increase in postprandial MPS in response to exercise was persistent after 24 hours after exercise [47]. Another study [42] investigated MPS in response to wholebody resistance exercise and only included methods using $20 \mathrm{~g}$ and $40 \mathrm{~g}$ of whey protein. In contrast to studies that measured MPS in a single muscle, $40 \mathrm{~g}$ of bolus whey protein induced a $20 \%$ higher FSR than the $20 \mathrm{~g}$ dose, however the total muscle involved in the exercise likely influenced the dose-response of MPS [42].

\section{MPS dose-response in elderly individuals}

Comparing the MPS responses in young versus elderly individuals may provide insight on the effects of aging on maximal MPS responses and anabolic resistance. Several studies have investigated the MPS response to protein ingestion at rest and after resistance exercise in elderly. Dose-response studies have confirmed that older adults can reach an approximately equal maximal MPS as younger adults, however they need to consume more protein in order to stimulate this maximal response [48, 49].

The optimal dose needed to elicit maximal MPS in rested, elderly muscle is not well established [4]. One study by Yang et al. reported no significant difference in FSR between ingestion of $20 \mathrm{~g}$ and $40 \mathrm{~g}$ of whey protein, but there was a significant increase in consuming $20 \mathrm{~g}$ or $40 \mathrm{~g}$ compared to $0 \mathrm{~g}$ [48]. In a subsequent experiment using soy protein instead of whey protein, the authors found that at rest neither $20 \mathrm{~g}$ or $40 \mathrm{~g}$ elicited a significant difference in FSR from basal values like the whey protein had [49]. Moreover, the study using whey protein was included in a retrospective analysis investigating the relative (to body weight) protein required to stimulate maximal MPS at rest, and found that older men require $0.4 \mathrm{~g} / \mathrm{kg} / \mathrm{meal}$ [6]. Applying this figure to the average weight of the participants included in the whey protein study would imply that $\sim 30 \mathrm{~g}$ of whey protein elicits maximal MPS, not $20 \mathrm{~g}$.

In exercised muscle, resistance training potentiates the MPS response to whey protein. Yang et al. found that FSR was greater in the exercised muscle compared to the nonexercised muscle for all whey doses [48]. Unlike the results from rested state, there was a significant increase in FSR (32\%) following $40 \mathrm{~g}$ of whey protein ingestion compared to $20 \mathrm{~g}$ for the exercised muscle [48]. The requirement of a substantially greater protein dose to stimulate maximal MPS in exercised elderly muscle is generally agreed upon across different types of protein. In the study conducted by the same authors using soy protein, $40 \mathrm{~g}$ was also found to stimulate significantly increased MPS [49]. $36 \mathrm{~g}$ of beef protein elicited the greatest MPS compared to lower doses, however, there was also a marked increase in AA oxidation [50]. The participants of this study were middle-aged adults ( 60 years old), and there was little difference between the MPS dose-response of these individuals versus elderly adults [50].

Low doses of whey, soy, and beef protein $(0-10 \mathrm{~g})$ elicited blunted MPS responses in both rested and exercised older muscles [6, 41, 48-50]. This form of anabolic resistance has been shown to be correlated with reduced p70S6K1 phosphorylation in the mTORC1pathway [30]. $40 \mathrm{~g}$ of whey protein was found to induce the greatest and most sustained increase in p70S6K1 phosphorylation when compared to other doses [51].

\section{Discussion}

In efforts to reduce sarcopenia, increasing MPS in older adults has been extensively studied. Dose-response curves provide insight on the optimal bolus protein dose to elicit a maximal MPS response. In addition, comparing MPS markers between younger and older individuals may reveal effects of aging on relevant pathways, such as mTORC1.

At rest, the most effective protein dose for older individuals is inconclusive. Two studies conducted by Yang et al. using whey and soy protein found that $20 \mathrm{~g}$ of whey protein was sufficient to elicit maximal MPS at rest in elderly individuals, but ingestion of neither $20 \mathrm{~g}$ nor $40 \mathrm{~g}$ of soy protein stimulated a significant increase in MPS 
UNDERGRADUATE RESEARCH IN NATURAL AND CLINICAL SCIENCE AND TECHNOLOGY (URNCST) JOURNAL Read more URNCST Journal articles and submit your own today at: https://www.urncst.com

[48, 49]. These differing results may in part be due to the faster digestion and absorption kinetics of whey protein [52]. However, the results from the whey protein study conducted by Yang et al. [48] are at odds with the retrospective analysis by Moore et al. [6], which suggests a $30 \mathrm{~g}$ dose of whey protein required to stimulate maximal MPS in the participants in Yang et al.'s study. It is important to note only 2 out of the 6 papers included in the analysis included elderly individuals as participants in experiments, one of these papers being the whey protein study by Yang et al. [6]. The other paper did not measure acute MPS nor did it include a dose-response in the study design [53]. Therefore, no definitive optimal dose to stimulate maximal MPS at rest has been reported.

More studies have conducted MPS dose-response curves in resistance-exercised muscle. Numerous studies have reported that $\sim 35-40 \mathrm{~g}$ of protein (whey, soy, and beef) elicits MPS responses similar to those of young individuals [48-50, 54]. Moreover, there is a significant increase in AA oxidation at this protein dose, suggesting that even greater doses may result in inefficient consumption of protein [50]. With this said, these recent dose-responses lack a plateau that is characteristic of the muscle full effect seen in younger adults, and the effects of doses greater than $40 \mathrm{~g}$ of protein on exercised muscle have not been thoroughly explored [4].

The studies included in this review use different types of protein, including whey, soy, and beef. However, the type of protein influences rates of postprandial MPS [52]. Whey protein contains high leucine content, which has been identified as one of the main nutritional signals to stimulate MPS through the mTORC1 pathway [52]. Furthermore, it is a fast-digestible protein, and may increase acute MPS more potently than other proteins [52]. Compared to soy protein, whey produces a significantly increased FSR following resistance exercise, but there is only a slight, non-significant increase in the rested state [55]. Contrastingly, beef is a slow-digestible protein, producing sustained increases in plasma AA concentrations over hours, compared to the peak in plasma AA concentration at 30 minutes following consumption by whey protein [56]. The rate of digestion affects the effect of the protein on acute MPS.

In addition to the various types of proteins studied, there has also been interest in investigating the effects of supplemental leucine on MPS. As aforementioned, leucine is regarded as a trigger of MPS, and studies involving both young and elderly participants have concluded that leucine supplementation can significantly increase MPS independent of other AAs [57, 58]. In young, exercised males, a low protein dosage supplemented with a high leucine dosage elicited the same FSR rates as a high dose of protein [58]. For elderly individuals, leucine supplementation has been proposed as a method to slow the effects of sarcopenia [59].

The most agreed upon results include that older individuals exhibit anabolic resistance to protein ingestion, and this has been proven through reduced phosphorylation of downstream targets in the mTORC1 pathway [30]. Additionally, greater protein doses are required for older individuals to elicit a maximal MPS response comparable to their younger counterparts [6]. These conclusions are broad and further research must be conducted to come to a consensus on the optimal dosage required for maximal MPS in older individuals. Additionally, only one study has conducted a dose-response with middle aged ( $\sim 0$ years old) adults, and no differences in MPS dose-response between middle-aged and elderly individuals [50]. Further research to include a more diverse age range is required to better understand this across the lifespan.

\section{Conclusions}

Overall, this review summarized the findings in published MPS dose-response experiments following protein ingestion in rested and exercised muscle. Comparing MPS responses between younger and older individuals, older muscle is resistant to anabolic stimuli, requiring greater protein doses to achieve maximal MPS in the exercised state. Approximately $35-40 \mathrm{~g}$ of whey protein is required to stimulate elderly MPS rates similar to those of maximal young MPS rates in exercised muscle. Further research must be conducted to clearly establish the doseresponse in rested muscle, but a practical consumption dosage between 20-30g of whey protein per meal or sitting is likely sufficient to stimulate maximal MPS. Confirming the MPS dose-response in older individuals will inform future recommendations on protein ingestion to minimize the effects of sarcopenia.

\section{List of Abbreviations Used}

MPS: muscle protein synthesis

FSR: fractional synthetic rate

AA: amino acid

mTORC1: mammalian target of rapamycin complex 1

4E-BP1/2: eukaryotic initiation factor $4 \mathrm{E}$ binding proteins

1 and 2

S6K1/2: ribosomal S6 kinases 1 and 2

eIF4E: eukaryotic initiation factor $4 \mathrm{E}$

EAA: essential amino acid

TNF- $\alpha$ : tumor necrosis factor alpha

IL-6: interleukin 6

\section{Conflicts of Interest}

The author declares that she has no conflict of interests.

\section{Ethics Approval and/or Participant Consent}

This literature review did not require ethics approval and/or participant consent.

\section{Authors' Contributions}

CQ: contributed to the conception of study, conducted literature review, analysed and interpreted data, drafted the manuscript, and gave final approval of the version to be published. 
UNDERGRADUATE RESEARCH IN NATURAL AND CLINICAL SCIENCE AND TECHNOLOGY (URNCST) JOURNAL Read more URNCST Journal articles and submit your own today at: https://www.urncst.com

\section{Funding}

This study was not funded.

\section{References}

[1] Santilli V, Bernetti A, Mangone M, Paoloni M. Clinical definition of sarcopenia. Clinical Cases in Mineral and Bone Metabolism. 2014 Sep;11(3); 177-180. https://doi.org/10.11138/ccmbm/2014.11.3 .177

[2] Stec MJ, Thalacker-Mercer A, Mayhew DL, Kelly NA, Tuggle SC, Merritt EK, et al. Randomized, four-arm, dose-response clinical trial to optimize resistance exercise training for older adults with age-related muscle atrophy. Experimental Gerontology. 2017 Dec;99;98109. https://doi.org/10.1016/j.exger.2017.09.018

[3] Yarasheski KE. Review Article: Exercise, Aging, and Muscle Protein Metabolism. The Journals of Gerontology. 2003 Oct;58(10);918-922. https://doi.org/10.1093/gerona 158.10.M918

[4] Witard O, Wardle S, Macnaughton L, Hodgson A, Tipton K. Protein Considerations for Optimising Skeletal Muscle Mass in Healthy Young and Older Adults. Nutrients. 2016 Apr;8(4);181. https://doi.org/ 10.3390/nu8040181

[5] Pennings B, Koopman R, Beelen M, Senden JM, Saris WH, Loon LJ. Exercising before protein intake allows for greater use of dietary protein-derived amino acids for de novo muscle protein synthesis in both young and elderly men. The American Journal of Clinical Nutrition. 2011 Feb;93(2);322-331. https://doi.org/10.3945/ajen .2010 .29649

[6] Moore DR, Churchward-Venne TA, Witard O, Breen L, Burd NA, Tipton KD, et al. Protein Ingestion to Stimulate Myofibrillar Protein Synthesis Requires Greater Relative Protein Intakes in Healthy Older Versus Younger Men. The Journals of Gerontology Series A: Biological Sciences and Medical Sciences, 2014 Jul;70(1);57-62. https://doi.org/10.1093/gerona/glu103

[7] Chesley A, Macdougall JD, Tarnopolsky MA, Atkinson SA, Smith K. Changes in human muscle protein synthesis after resistance exercise. Journal of Applied Physiology. 1992 Nov;73(4);1383-1388. https://doi.org/10.1152/jappl.1992.73.4.1383

[8] Drummond MJ, Fry CS, Glynn EL, Dreyer HC, Dhanani S, Timmerman KL, et al. Rapamycin administration in humans blocks the contractioninduced increase in skeletal muscle protein synthesis. The Journal of Physiology, 2009 Feb;587(7);15351546. Https://doi.org/10.1113/jphysiol.2008.163816

[9] Mcglory C, Phillips SM. Exercise and the Regulation of Skeletal Muscle Hypertrophy. Progress in Molecular Biology and Translational Science. 2015 Dec;135; 153-173. https://doi.org/10.1016/bs.pmbts.2015.06.018

[10] D'souza RF, Markworth JF, Figueiredo VC, Gatta PA, Petersen AC, Mitchell CJ, et al. Dose-dependent increases in p70S6K phosphorylation and intramuscular branched-chain amino acids in older men following resistance exercise and protein intake. Physiological Reports. 2014 Aug;2(8);e12112. https://doi.org/ $10.14814 / \mathrm{phy} 2.12112$

[11]Terzis G, Georgiadis G, Stratakos G, Vogiatzis I, Kavouras S, Manta P, et al. Resistance exerciseinduced increase in muscle mass correlates with p70S6 kinase phosphorylation in human subjects. European Journal of Applied Physiology. 2008 Jan;102(2);145152. https://doi.org/:10.1007/s00421-007-0564-y

[12] Bond P. Regulation of mTORC1 by growth factors, energy status, amino acids and mechanical stimuli at a glance. Journal of the International Society of Sports Nutrition. 2016 Mar;13(1);1-11. https://doi.org/10.1186/ s12970-016-0118-y

[13] Atherton PJ, Etheridge T, Watt PW, Wilkinson D, Selby A, Rankin D, et al. Muscle full effect after oral protein: Time-dependent concordance and discordance between human muscle protein synthesis and mTORC1 signaling. The American Journal of Clinical Nutrition. 2010 Nov;92(5);1080-1088. https://doi.org/10.3945/ ajcn.2010.29819

[14]Fry CS, Drummond MJ, Glynn EL, Dickinson JM, Gundermann DM, Timmerman KL, et al. Aging impairs contraction-induced human skeletal muscle mTORC1 signaling and protein synthesis. Skeletal Muscle. 2011 Mar;1(1);11. https://doi.org/10.1186/ 2044-5040-1-11

[15] Paddon-Jones D, Sheffield-Moore M, Katsanos CS, Zhang X, Wolfe RR. Differential stimulation of muscle protein synthesis in elderly humans following isocaloric ingestion of amino acids or whey protein. Experimental Gerontology. 2006 Feb;41(2); 215-219. https://doi.org/10.1016/j.exger.2005.10.006

[16] Bohé J, Low A, Wolfe RR, Rennie MJ. Human Muscle Protein Synthesis is Modulated by Extracellular, Not Intramuscular Amino Acid Availability: A DoseResponse Study. The Journal of Physiology. 2003 Oct;552(1);315-324. https://doi.org/10.1113/jphysiol .2003 .050674

[17] Moberg M, Apro W, Ekblom B, van Hall G, Holmberg $\mathrm{HC}$, Blomstrand E. Activation of mTORC1 by leucine is potentiated by branched-chain amino acids and even more so by essential amino acids following resistance exercise. American Journal of Cell Physiology. 2016 Jun;310;C874-C884. https://doi.org/10.1152/ajpcell .00374 .2015

[18] Atherton PJ, Smith K. Muscle protein synthesis in response to nutrition and exercise. The Journal of Physiology. 2012 Mar;590(5);1049-1057. https://doi.org/ 10.1113/jphysiol.2011.225003

[19] Biolo G, Tipton KD, Klein S, Wolfe RR. An abundant supply of amino acids enhances the metabolic effect of exercise on muscle protein. American Journal of Physiology-Endocrinology and Metabolism. 1997 
UNDERGRADUATE RESEARCH IN NATURAL AND CLINICAL SCIENCE AND TECHNOLOGY (URNCST) JOURNAL

Read more URNCST Journal articles and submit your own today at: https://www.urncst.com

Jul;273(1);E122-E129. https://doi.org/10.1152/ajpendo $.1997 .273 .1 . e 122$

[20] Atherton PJ, Kumar V, Selby AL, Rankin D, Hildebrandt W, Phillips BE, et al. Enriching a protein drink with leucine augments muscle protein synthesis after resistance exercise in young and older men. Clinical Nutrition. 2016 Apr;36(3);888-895. https://doi.org/ 10.1016/j.clnu.2016.04.025

[21] Dreyer HC, Fujita S, Cadenas JG, Chinkes DL, Volpi E, Rasmussen BB. Resistance exercise increases AMPK activity and reduces 4E-BP1 phosphorylation and protein synthesis in human skeletal muscle. The Journal of Physiology. 2006 Oct;576(2); 613-624. https://doi.org/10.1113/jphysiol.2006.113175

[22] Phillips SM, Tipton KD, Aarsland A, Wolf SE, Wolfe RR. Mixed muscle protein synthesis and breakdown after resistance exercise in humans. American Journal of Physiology-Endocrinology and Metabolism. 1997 Jul;273(1);E99-107. https://doi.org/10.1152/ajpendo 1997.273.1.e99

[23] Louis E, Raue U, Yang Y, Jemiolo B, Trappe S. Time course of proteolytic, cytokine, and myostatin gene expression after acute exercise in human skeletal muscle. Journal of Applied Physiology. 2007 Nov;103(5);17441751. https://doi.org/10.1152/japplphysiol.00679.2007

[24] Carraro F, Stuart CA, Hartl WH, Rosenblatt J, Wolfe RR. Effect of exercise and recovery on muscle protein synthesis in human subjects. American Journal of Physiology-Endocrinology and Metabolism. 1990 Oct;259(4);e470-e476. https://doi.org/10.1152/ajpendo $.1990 .259 .4 . e 470$

[25] Phillips SM, Tipton KD, Ferrando AA, Wolfe RR. Resistance training reduces the acute exercise-induced increase in muscle protein turnover. American Journal of Physiology-Endocrinology and Metabolism. 1999 Jan;276(1);e118-e124. https://doi.org/10.1152/ajpendo 1999.276.1.e118

[26] Tang JE, Perco JG, Moore DR, Wilkinson SB, Phillips SM. Resistance training alters the response of fed state mixed muscle protein synthesis in young men. American Journal of Physiology-Regulatory, Integrative and Comparative Physiology. 2008 Jan;294(1);1045-1053. https://doi.org/10.1152/ajpregu.00636.2007

[27] Markofski MM, Dickinson JM, Drummond MJ, Fry CS, Fujita S, Gundermann DM, et al. Effect of age on basal muscle protein synthesis and mTORC1 signaling in a large cohort of young and older men and women. Experimental Gerontology. 2015 Feb;65; 1-7. https://doi.org/10.1016/j.exger.2015.02.015

[28] Cuthbertson D, Smith K, Babraj J, Leese G, Waddell $\mathrm{T}$, Atherton $\mathrm{P}$, et al. Anabolic signaling deficits underlie amino acid resistance of wasting, aging muscle. The FASEB Journal. 2004 Jan;19(3);1-22. https://doi.org/10.1096/fj.04-2640fje

[29] Wilkinson DJ, Bukhari SS, Phillips BE, Limb MC, Cegielski J, Brook MS, et al. Effects of leucine- enriched essential amino acid and whey protein bolus dosing upon skeletal muscle protein synthesis at rest and after exercise in older women. Clinical Nutrition. 2017 Sept; 37(6); 2011-2021. https://doi.org/10.1016/j.clnu .2017 .09 .008

[30] Churchward-Venne TA, Holwerda AM, Phillips SM, Loon LJ. What is the Optimal Amount of Protein to Support Post-Exercise Skeletal Muscle Reconditioning in the Older Adult? Sports Medicine. 2016 Feb;46(9);1205-1212. https://doi.org/10.1007/s40279016-0504-2

[31] Rennie MJ. Anabolic resistance: The effects of aging, sexual dimorphism, and immobilization on human muscle protein turnover. Applied Physiology, Nutrition, and Metabolism. 2009 May;34(3);377-381. https://doi.org/10.1139/h09-012

[32] Murphy CH, Oikawa SY, Phillips SM. Dietary Protein to Maintain Muscle Mass in Aging: A Case for Per-meal Protein Recommendations. J Frailty Aging. 2016 Jan;5(1):49-58. $\quad$ https://doi.org/10.14283/jfa 2016.80

[33] Breen L, Phillips SM. Skeletal muscle protein metabolism in the elderly: Interventions to counteract the 'anabolic resistance' of ageing. Nutrition \& Metabolism. 2011 Oct;8(1);68. https://doi.org/10.1186/ 1743-7075-8-68

[34] Rea IM, Gibson DS, Mcgilligan V, Mcnerlan SE, Alexander HD, Ross OA. Age and Age-Related Diseases: Role of Inflammation Triggers and Cytokines. Frontiers in Immunology. 2018 Apr;9;1-28. https://doi.org/10.3389/fimmu.2018.00586

[35] Breuille D, Voisin L, Contrepois M, Arnal M, Rose F, Obled C. A Sustained Rat Model for Studying the LongLasting Catabolic State of Sepsis. Infection and Immunity. 1999 Mar;67(3);1079-1085. https://doi.org/10 $.1128 /$ iai.67.3.1079-1085.1999

[36] Toth MJ, Matthews DE, Tracy RP, Previs MJ. Agerelated differences in skeletal muscle protein synthesis: Relation to markers of immune activation. American Journal of Physiology-Endocrinology and Metabolism. 2005 May;288(5);1-9. https://doi.org/10.1152/ajpendo .00353 .2004

[37] Lang CH, Frost RA, Nairn AC, Maclean DA, Vary TC. TNF- $\alpha$ impairs heart and skeletal muscle protein synthesis by altering translation initiation. American Journal of Physiology-Endocrinology and Metabolism. 2002 Feb;282(2); 1-12. https://doi.org/10.1152/ajpendo .00366 .2001

[38] Kumar V, Selby A, Rankin D, Patel R, Atherton P, Hildebrandt W, et al. Age-related differences in the dose-response relationship of muscle protein synthesis to resistance exercise in young and old men. The Journal of Physiology. 2009 Jan;587(1); 211-217. https://doi.org/10.1113/jphysiol.2008.164483

[39] Haran PH, Rivas DA, Fielding RA. Role and potential mechanisms of anabolic resistance in sarcopenia. 
UNDERGRADUATE RESEARCH IN NATURAL AND CLINICAL SCIENCE AND TECHNOLOGY (URNCST) JOURNAL

Read more URNCST Journal articles and submit your own today at: https://www.urncst.com

Journal of Cachexia, Sarcopenia and Muscle. 2012 Sep 1;3(3);157-62. https://doi.org/10.1007/s13539-0120068-4

[40] Baumgartner RN. Body Composition in Healthy Aging. Annals of the New York Academy of Sciences, 2006 Jan;904;437-448. https://doi.org/10.1111/j.17496632.2000.tb06498.x

[41] Smeuninx B, Mckendry J, Wilson D, Martin U, Breen L. Age-Related Anabolic Resistance of Myofibrillar Protein Synthesis Is Exacerbated in Obese Inactive Individuals. The Journal of Clinical Endocrinology \& Metabolism. 2017 Sep;102(9);3535-3545. https://doi.org/ 10.1210/jc.2017-00869

[42] Macnaughton LS, Wardle SL, Witard OC, Mcglory C, Hamilton DL, Jeromson S, et al. The response of muscle protein synthesis following whole-body resistance exercise is greater following $40 \mathrm{~g}$ than $20 \mathrm{~g}$ of ingested whey protein. Physiological Reports. 2016 Aug;4(15);1-13. https://doi.org/10.14814/phy2.12893

[43] Witard OC, Jackman SR, Breen L, Smith K, Selby A, Tipton KD. Myofibrillar muscle protein synthesis rates subsequent to a meal in response to increasing doses of whey protein at rest and after resistance exercise. The American Journal of Clinical Nutrition. 2013 Nov;99(1);86-95. https://doi.org/10.3945/ajen.112 .055517

[44] Moore DR, Robinson MJ, Fry JL, Tang JE, Glover EI, Wilkinson SB, et al. Ingested protein dose response of muscle and albumin protein synthesis after resistance exercise in young men. The American Journal of Clinical Nutrition. 2009 Jan;89(1);161-168. https://doi.org/10.3945/ajen.2008.26401

[45] Wolfe RR. Skeletal Muscle Protein Metabolism and Resistance Exercise. The Journal of Nutrition. 2006 Feb;136(2);525S-528S. https://doi.org/10.1093/jn/136.2 $.525 \mathrm{~S}$

[46] Moore DR, Tang JE, Burd NA, Rerecich T, Tarnopolsky MA, Phillips SM. Differential stimulation of myofibrillar and sarcoplasmic protein synthesis with protein ingestion at rest and after resistance exercise. The Journal of Physiology. 2009 Feb;587(4);897-904. https://doi.org/10.1113/jphysiol.2008.164087

[47] Burd NA, West DW, Moore DR, Atherton PJ, Staples AW, Prior T, et al. Enhanced Amino Acid Sensitivity of Myofibrillar Protein Synthesis Persists for up to $24 \mathrm{~h}$ after Resistance Exercise in Young Men. The Journal of Nutrition. $2011 \mathrm{Feb}$;141(4);568-573. https://doi.org/ 10.3945/jn.110.135038

[48] Yang Y, Breen L, Burd NA, Hector AJ, ChurchwardVenne TA, Josse AR, et al. Resistance exercise enhances myofibrillar protein synthesis with graded intakes of whey protein in older men. British Journal of Nutrition. 2012 Nov;108(10);1780-1788. https://doi.org/ 10.1017/s0007114511007422

[49] Yang Y, Churchward-Venne TA, Burd NA, Breen L, Tarnopolsky MA, Phillips SM. Myofibrillar protein synthesis following ingestion of soy protein isolate at rest and after resistance exercise in elderly men. Nutrition \& Metabolism. 2012 June;9(1);57. https://doi.org/10.1186/1743-7075-9-57

[50] Robinson MJ, Burd NA, Breen L, Rerecich T, Yang Y, Hector AJ, et al. Dose-dependent responses of myofibrillar protein synthesis with beef ingestion are enhanced with resistance exercise in middle-aged men. Applied Physiology, Nutrition, and Metabolism. 2013 Feb;38(2);120-125. https://doi.org/10.1139/apnm2012-0092

[51] Wilkinson DJ, Bukhari SS, Phillips BE, Limb MC, Cegielski J, Brook MS, et al. Effects of leucineenriched essential amino acid and whey protein bolus dosing upon skeletal muscle protein synthesis at rest and after exercise in older women. Clinical Nutrition. 2018 Dec;37(6);2011-2021. https://doi.org/10.1016/ j.clnu.2017.09.008

[52] Pennings B, Boirie Y, Senden JM, Gijsen AP, Kuipers $\mathrm{H}$, Loon LJ. Whey protein stimulates postprandial muscle protein accretion more effectively than do casein and casein hydrolysate in older men. The American Journal of Clinical Nutrition. 2011 Mar;93(5);997-1005. https://doi.org/10.3945/ajen.110 .008102

[53] Breen L, Stokes KA, Churchward-Venne TA, Moore DR, Baker SK, Smith K, et al. Two Weeks of Reduced Activity Decreases Leg Lean Mass and Induces "Anabolic Resistance" of Myofibrillar Protein Synthesis in Healthy Elderly. The Journal of Clinical Endocrinology \& Metabolism. 2013 Apr;98(6);26042612. https://doi.org/10.1210/jc.2013-1502

[54] Pennings B, Groen B, Lange AD, Gijsen AP, Zorenc AH, Senden JM, et al. Amino acid absorption and subsequent muscle protein accretion following graded intakes of whey protein in elderly men. American Journal of Physiology-Endocrinology and Metabolism. 2012 Apr;302(8);E992-E999. https://doi.org/10.1152/ ajpendo.00517.2011

[55] Tang JE, Moore DR, Kujbida GW, Tarnopolsky MA, Phillips SM. Ingestion of whey hydrolysate, casein, or soy protein isolate: Effects on mixed muscle protein synthesis at rest and following resistance exercise in young men. Journal of Applied Physiology. 2009 Jul;107(3);987-992. https://doi.org/10.1152/japplphysiol .00076 .2009

[56] Detzel C, Petschow BW, Johnson N, Weaver EM. Comparison of the Amino Acid and Peptide Composition and Postprandial Response of Beef, Chicken, and Whey Protein Nutritional Preparations. Functional Foods in Health and Disease. 2016 Oct;6(10);612. https://doi.org/10.31989/ffhd.v6i10.308

[57]Rieu I, Balage M, Sornet C, Giraudet C, Pujos E, Grizard J, et al. Leucine supplementation improves muscle protein synthesis in elderly men independently of hyperaminoacidaemia. The Journal of Physiology. 
UNDERGRADUATE RESEARCH IN NATURAL AND CLINICAL SCIENCE AND TECHNOLOGY (URNCST) JOURNAL Read more URNCST Journal articles and submit your own today at: https://www.urncst.com

2006 Aug;575(1);305-315. https://doi.org/10.1113/ jphysiol.2006.110742

[58] Churchward-Venne TA, Breen L, Di Donato DM, Hector AJ, Mitchell CJ, Moore DR, et al. Leucine supplementation of a low-protein mixed macronutrient beverage enhances myofibrillar protein synthesis in young men: a double-blind, randomized trial. The
American Journal of Clinical Nutrition. 2014 Feb;99(2);276-286. https://doi.org/10.3945/ajcn.113 .068775

[59] Elango R, Rasmussen B, Madden K. Safety and Tolerability of Leucine Supplementation in Elderly Men. The Journal of Nutrition. 2016 Dec;146(12);2630S2634S. https://doi.org/10.3945/jn.116.234930

\section{Article Information}

Managing Editor: Jeremy Y. Ng

Peer Reviewers: Brad Currier, Aaron Thomas

Article Dates: Received Nov 15 20; Accepted Feb 15 21; Published Mar 2421

\section{Citation}

Please cite this article as follows:

Qian C. Dose-dependent effects of protein ingestion and resistance exercise on muscle protein synthesis in aging adults: A literature review. URNCST Journal. 2021 Mar 24: 5(3). https://urncst.com/index.php/urncst/article/view/226

DOI Link: https://doi.org/10.26685/urncst.226

\section{Copyright}

(C) Caryn Qian. (2021). Published first in the Undergraduate Research in Natural and Clinical Science and Technology (URNCST) Journal. This is an open access article distributed under the terms of the Creative Commons Attribution License (https://creativecommons.org/licenses/by/4.0/), which permits unrestricted use, distribution, and reproduction in any medium, provided the original work, first published in the Undergraduate Research in Natural and Clinical Science and Technology (URNCST) Journal, is properly cited. The complete bibliographic information, a link to the original publication on http://www.urncst.com, as well as this copyright and license information must be included.
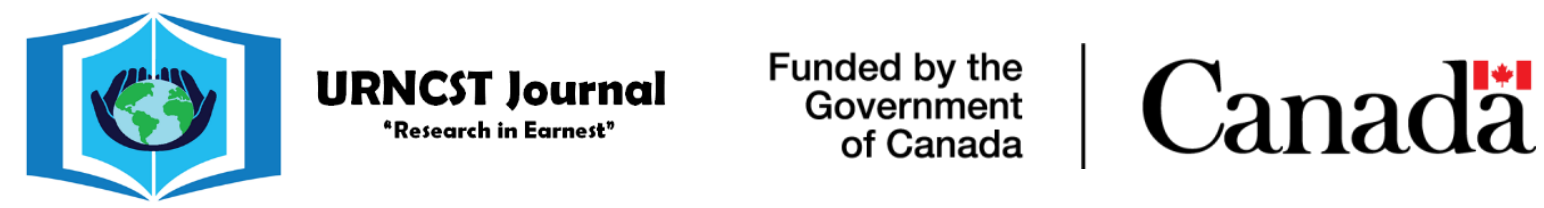

Do you research in earnest? Submit your next undergraduate research article to the URNCST Journal!

| Open Access | Peer-Reviewed | Rapid Turnaround Time | International |

| Broad and Multidisciplinary | Indexed | Innovative | Social Media Promoted |

Pre-submission inquiries? Send us an email at info@ urncst.com | Facebook, Twitter and LinkedIn: @URNCST

Submit YOUR manuscript today at https://www.urncst.com! 